OZAKI AKIHIRO ${ }^{1}$

\title{
THE MEETING OF ASIA AND THE NETHERLANDS: ON VAN GOGH'S CHALLENGE IN EMULATING REMBRANDT
}

\begin{abstract}
The essay grew out of an issue I had been pondering for some time and is an attempt to gain an insight into a secret van Gogh was eager to discover while comparing himself as an artist with "Rembrandt, the magician". Van Gogh was convinced that art could succeed where religion had failed. Moreover, there was no need for art to be directly connected with Christianity as a system. For van Gogh, in this frame of mind, the art of "Japan", as exemplified by the genre of ukiyo-e, and such like, provided hope. Rembrandt, too, saw oriental art not so much as art in itself but as a method of expressing one's innermost feelings that were still lacking in European art, and that were, moreover, understood as a source of inspiration for the creation of a new, ideal form of human compassion. Similarly, van Gogh's art was distilled into a more essential form of itself as his inspiration from the ukiyo-e genre gradually deepened and became more internalized. Therefore, this is something he shared with Rembrandt and what related him more closely to the oriental art apparent in work of the Old Master.
\end{abstract}

Keywords: van Gogh, Rembrandt

Europe's dramatic encounter with Japan in the 19th century can also be seen in regards to Netherlands from the latter half of the 16th century through the 17th century.

The Age of Discovery quickly broadened the geographical horizons of Europeans, not through mythologizing the Biblical world underpinning their Christian faith, but thanks to the development of archaeology and

${ }^{1}$ Prof.; Tohoku University; ORCID: 0000-0002-4740-6417;

akihiro.ozaki.c5@tohoku.ac.jp. 
natural sciences. As a result, in order to integrate space and time, they invented the idea of progress. In a contemporary world that aims to globalize, what is required of the humanities, including Art History, is a new approach to a situation such as globalization. The following essay grew out of the issue I had been pondering and is an attempt to gain an insight into the secret van Gogh was eager to uncover while comparing himself as an artist with "Rembrandt, the magician" (van Gogh, 1888a).

After two years of living with his brother, Theo, Vincent van Gogh moved out at the end of February, 1888, and headed to Arles in the south of France. Having taken the overnight train, on his arrival that morning, he wrote to Theo: "I feel I'm in Japan" (van Gogh, 1888b). It was snowing and flakes of snow swirled about him against a backdrop of white mountain peaks: this was "just like the winter landscapes the Japanese did" (van Gogh, 1888c), as van Gogh wrote to his brother, in a letter that openly expressed his enthusiasm. This time his plan was to fulfill a long-held dream of setting up an artists' colony and which would be based in the "Yellow House" (van Gogh, 1888d) where van Gogh had rented lodgings.

In fact, in a letter addressed to Theo in September 1882, van Gogh had already written about the ideals of the community of artists:

In the last few days I've been reading Les deux frères by Erckmann-Chatrian, which is quite beautiful. It was certainly an interesting time when there were so many artists in Alsace: Brion, Marchal, Jundt, Vautier, Knaus, Schuler, Saal, Van Muyden, and many others surely - at the same time as a group of writers working in the same spirit like Chatrian and Auerbach. (van Gogh, 1882)

The image of the community of artists that van Gogh had was a projection of images of Japanese artists. He wrote in a letter to Emile Bernard:

For a long time I've been touched by the fact that Japanese artists very often made exchanges among themselves. It clearly proves that they liked one another and stuck together, and that there was a certain harmony among them and that they did indeed live a kind of brotherly life, in a natural way and not in the midst of intrigues. The more we resemble them in that respect, the better it will be for us. It seems, too, that those Japanese earned very little money and lived like simple laborers. (van Gogh, 1888e)

Van Gogh's artist community, although based on a misunderstanding, had become an idealized utopia, an imitation of Japanese artists, and a place where artists could create independently of art dealers. 
In September 1888, van Gogh chose Gauguin as his companion. Subsequently, van Gogh suggested exchanging self-portraits (Figs. 1-2). This was particularly significant as he intended to put into practice something that was of special interest to him, namely the belief that "Japanese artists very often made exchanges among themselves" (van Gogh, 1888e). Van Gogh held that the exchange of self-portraits was needed to authenticate their passage into his utopian Japan (Kōdera, 1990 pp. 11-45). Gauguin responded by immediate sending a self-portrait. In Self-portrait (Les Misérables) he appears as Jean Valjean, the protagonist of Victor Hugo's novel Les Misérables (1862). Gauguin wrote to van Gogh explaining that in Self-portrait (Les Misérables) the color tones had been darkened, which also reflected the rebellious nature of the soul they depicted (Gauguin, 1888).

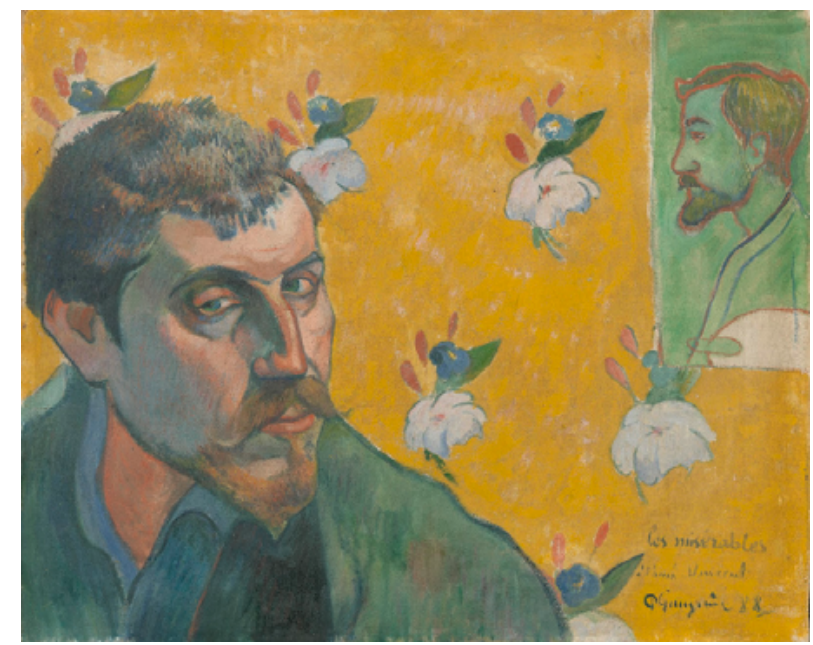

Fig. 1. Gauguin, Self-Portrait as Jean Valjean, 1888, Amsterdam, Van Gogh Museum (c) Van Gogh Museum, Amsterdam

On seeing Gauguin's unorthodox self-portrait, van Gogh acknowledged that though they were both striving to produce original art, there was a negative side to this (van Gogh, 1888f). Gauguin was seeking to achieve success merely by trying to be artistically different from other artists. Van Gogh himself said that if we study art as a substitute for religion then it should be something that is life-affirming and joyful. In a letter sent to his brother Theo in the fall of 1888 , there is the following passage: 


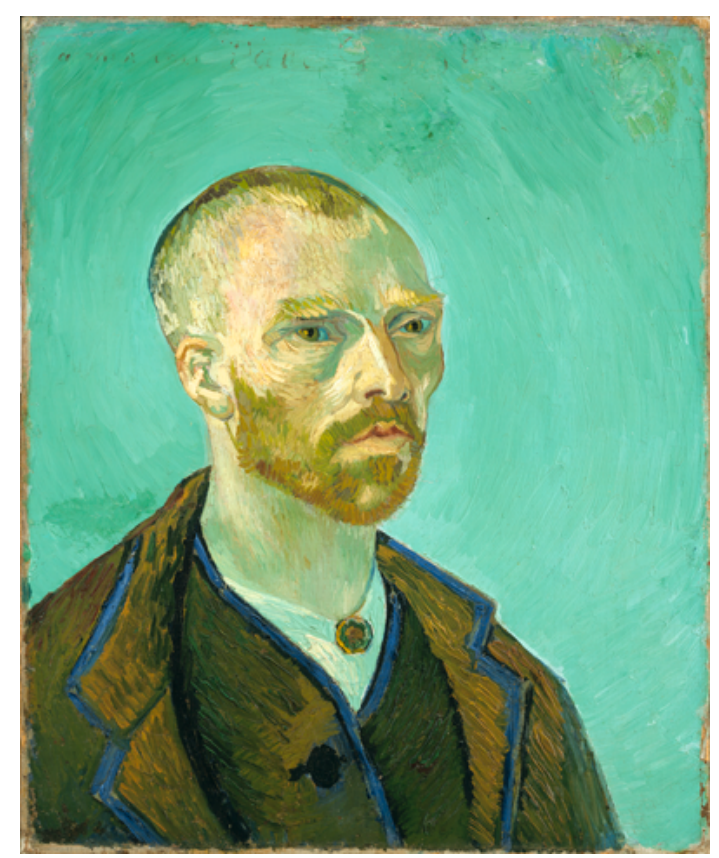

Fig. 2. Van Gogh, Self-Portrait as bonze, 1888, Cambridge, Fogg Art Museum (C) Harvard Art Museums

My portrait that I'm sending to Gauguin in exchange stands up beside it, I'm sure. I wrote to Gauguin in reply to his letter that if I too was allowed to enhance my personality in a portrait, trying to show in my portrait not only myself but an Impressionist in general, I had conceived this portrait as being that of a bonze, a simple worshipper of the eternal Buddha. (van Gogh, 1888f)

When van Gogh suggested to Gauguin that they exchange self-portraits, he had in fact already completed his own self-portrait. This was Self-Portrait (Dedicated to Paul Gauguin) where he is indeed portrayed as a bonze, or Buddhist monk (Figs. 2-3).

Here, he is painted in three-quarter profile, with a shaved pate and a casually-worn brown jacket, against a background of bluish light green. His face is gaunt and his eyes have been painted slanting upwards slightly, the western manner, used since ancient times, of depicting oriental figures. The light background and the somewhat serious face provide a contrast, while there are highlights in the eyes to make them stand out. These are no ordinary eyes; there is a glint in them and they seem to be looking into the 


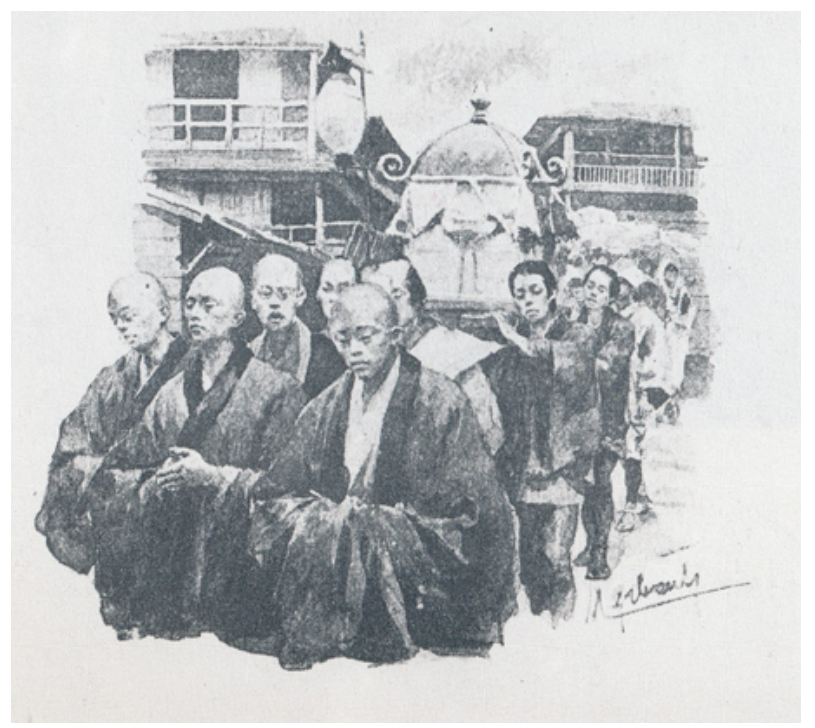

Fig. 3. Funeral procession: illustration to P. Loti, Madame Chrysanthème, Paris 1888

distance, expressing something regarding the future. Van Gogh wrote about this self-portrait, saying "I looked more for the character of a bonze, a simple worshiper of the eternal Buddha" (van Gogh, 1888g). Associating himself with a Japanese monk was not presumption on van Gogh's part. Although he was angry and profoundly disillusioned with the structure of the Christian church of his time, he had not repudiated Christianity per se. The sower was a theme that appeared frequently in his paintings from this period and he was profoundly influenced by the Bible. Yet, if this were so, why did he not choose to paint the prophets or saints that were mentioned in the Bible? Van Gogh felt a sense of despair towards Europe. Christianity was firmly rooted in the social order and held that it was not possible to save every soul.

However, van Gogh was convinced that art could succeed where religion had failed. Moreover, there was no need for art to be directly connected with Christianity as a system, which was by now an empty shell. For van Gogh in this frame of mind, the art of "Japan", as exemplified by the ukiyo-e, and such like, provided hope. Could this strong desire to save the future have been why he painted his self-portrait dressed as a bonze, a visual symbol of Japan? In substance, the meaning of the "self-portrait of the soul" was that art had become a new religion. 
In response, Gauguin's attempt to convey spirituality by means of color-based images, his introduction of naivety in painting, his suppression of depth, through the use of non-European patterns or drastic innovations, which were essentially rooted within a European framework, were nothing more than mere artistic experimentation in van Gogh's opinion. He himself had left all this behind and was pursuing a new form of art for the future. Thus, would not van Gogh, who was so critical of the institutional structures that governed their time, have seen Gauguin's self-portrait as belonging to that same institutional framework? The portrait of the artist, who is not free, is melancholic.

These very different approaches of van Gogh and Gauguin reached an irreconcilable point with the "ear-cutting incident", following which van Gogh voluntarily entered an asylum in Saint-Remy, a small town about twenty kilometers to the north-east of Arles. Self-portrait with Bandaged Ear (Fig. 4) was painted around this time. It is not only the sympathetic figure of the wounded, self-harming painter that draws the viewer's attention

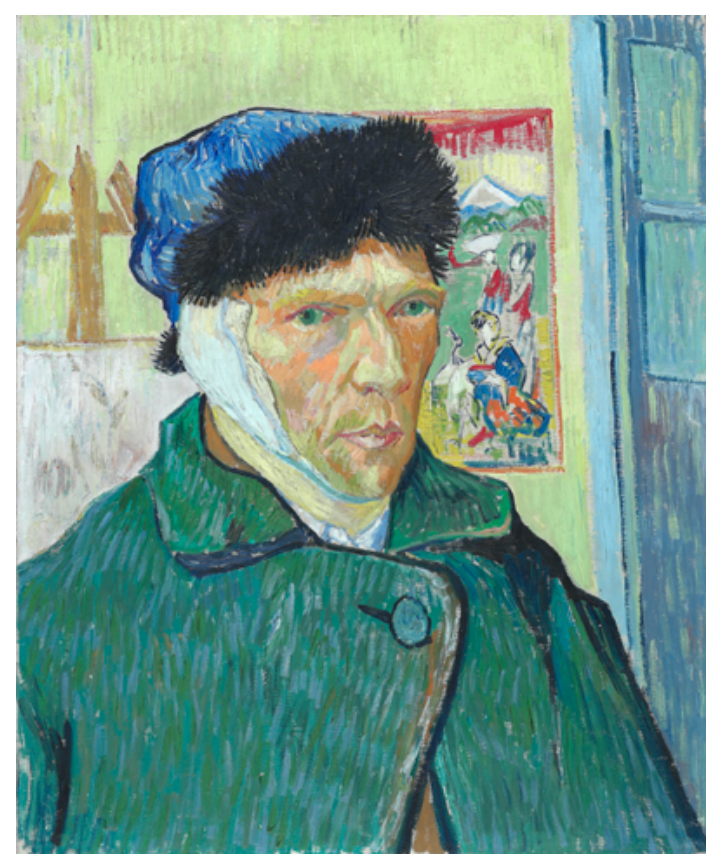

Fig. 4. Van Gogh, Self-portrait with Bandaged Ear,1889, London, The Courtauld Art Gallery (c) The Courtauld Art Gallery 
in this self-portrait. On the wall behind van Gogh an ukiyo-e print shows a geisha in the foreground with Mount Fuji in the distance. As Self-Portrait with Bandaged Ear was not the first time van Gogh had included an ukiyo-e print in one of his self-portraits, here I would like to refer to a most interesting case.

Café Terrace at Night (Fig. 5) shows the exterior of a café in the central square of Arles. In this painting, there is a star-filled night sky and the café stands out in the yellow light, but this work may never have existed had it not been for the bright night sky in Hiroshige's ukiyo-e that provided the inspiration for its creation (Fig. 6). In fact, from Impressionism onward, and not only in the works of van Gogh, figurative space in European painting rapidly became brighter, a phenomenon which would have been unthinkable without the influence of Japanese ukiyo-e.

In this frame of mind, van Gogh could not have failed to notice how Rembrandt had also successfully introduced oriental features into his painting. On deciding to become a painter, van Gogh wrote to his brother

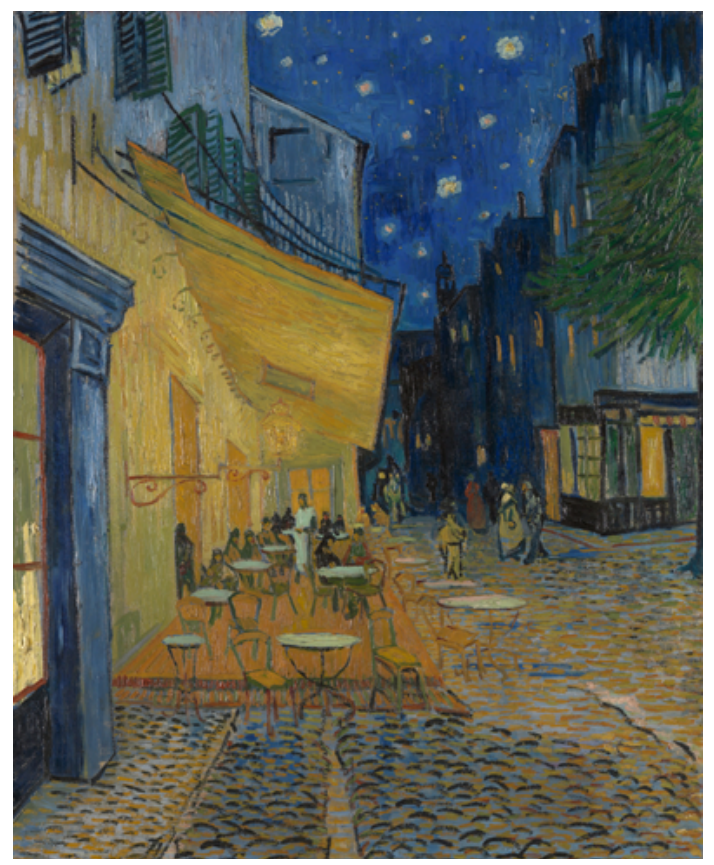

Fig. 5. Van Gogh, Café Terrace at Night, 1888. Otterlo, Kröller Müller Museum (c) Kröller Müller Museum 


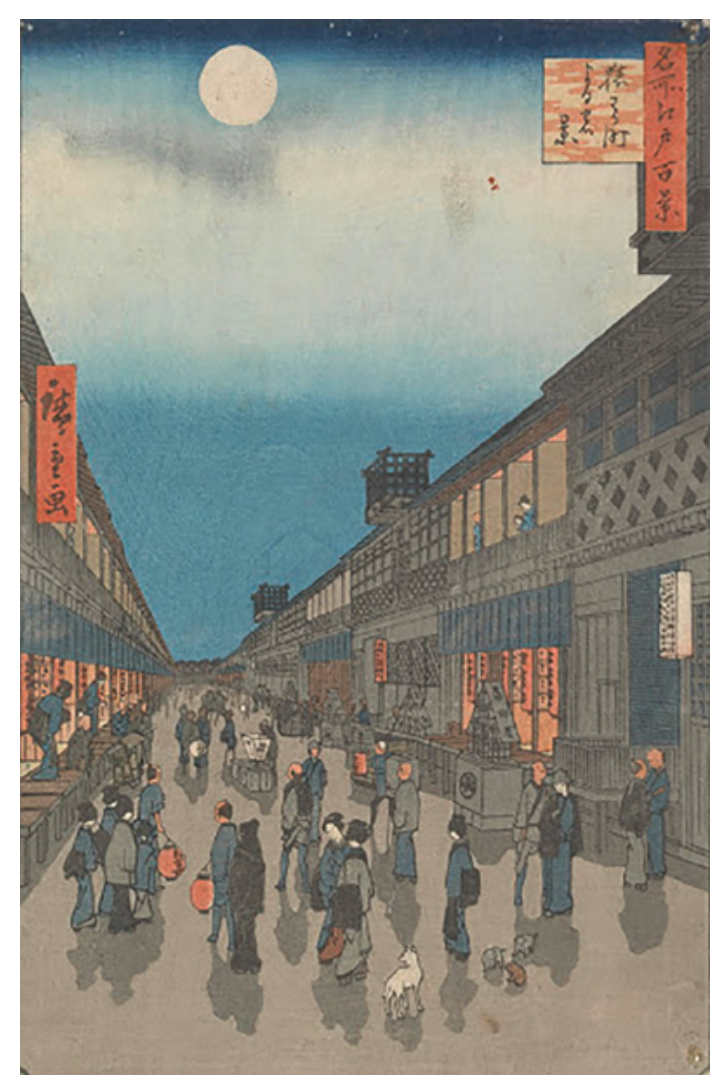

Fig. 6. Hiroshige (歌川広重), View of the Saruwakacho theatre street by night, 1856, Amsterdam, Van Gogh Museum. (C) Van Gogh Museum, Amsterdam

Theo, "I don't know how many times I would have to be born to be able to paint a picture like Rembrandt" (van Gogh, 1885). An example of this were the small objects that brought a world into play that was far-removed in both time and place, as in Jael Kills Sisera (Judges, 4: 7-14) where a Japanese helmet is shown in the background of a drawing showing a scene from the Old Testament (Fig. 7) (Exh. cat. 1999, p. 124; Ozaki, 2004, esp. pp. 197-198; Ozaki, 2014, esp. pp. 151-152).

Rembrandt portrays himself as a beggar (Fig. 8), then as a member of the royal family; as an artist he enjoyed role-playing and protean displays of disguise. One example of these paintings in which he role-plays is Self-Portrait in Oriental Attire, with Poodle (Paris, Musée du Petit Palais), 


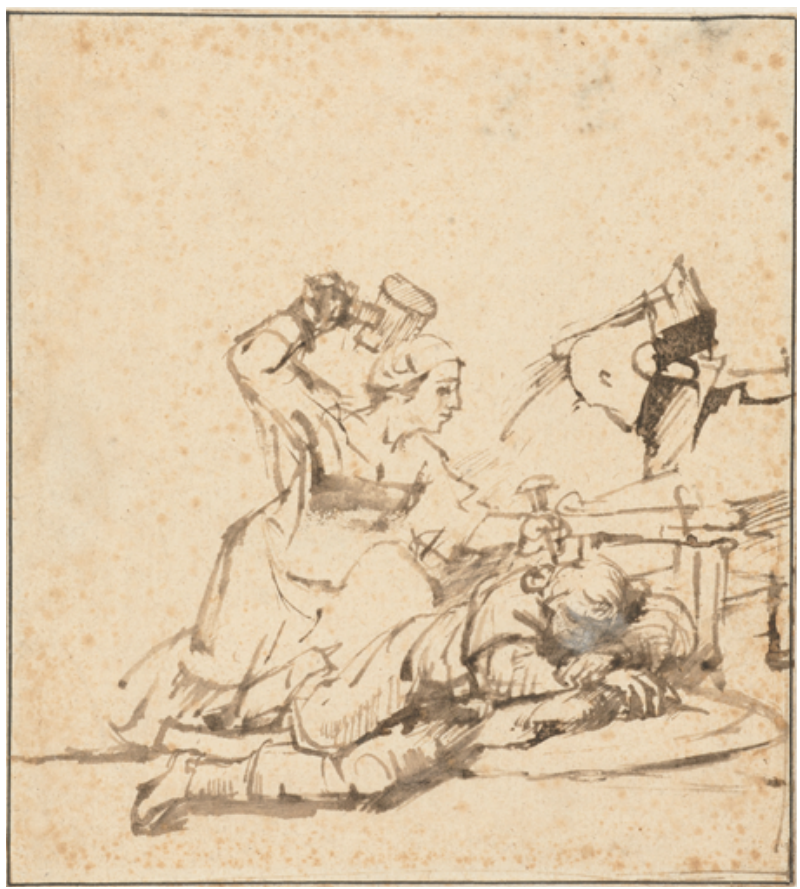

Fig. 7. Rembrandt, Jael Kills Sisera, 1657-59, Amsterdam, Rijksmuseum (C) Amsterdam, Rijksmuseum

where he is dressed in oriental-style costume. This work was painted either just before or just after he moved from his home town of Leiden to Amsterdam.

Rembrandt also made etchings of his self-portraits dressed in oriental costume (which were, in fact, middle-eastern characters). These include Self-Portrait as an Oriental Potentate with a Kris (Fig. 9) and Self-Portrait with Plumed Cap and Oriental Sabre (Fig. 10). In all his prints from the early 1630 's, the costumes and personal effects are depicted in minute detail, in all their stately grandeur. However, Rembrandt did not only paint selfportraits in oriental costume. There are also portraits known as "tronies" (Fig. 11) (literally "head") (these are not portraits of particular people, but paintings representing facial expressions or heads) based on Old Testament stories, which invariably contain characters in oriental costume. Interestingly, several artists who had been in close contact with Rembrandt later turned up in Batavia. Moreover, Rembrandt's own daughter, Cornelia ended up there. 


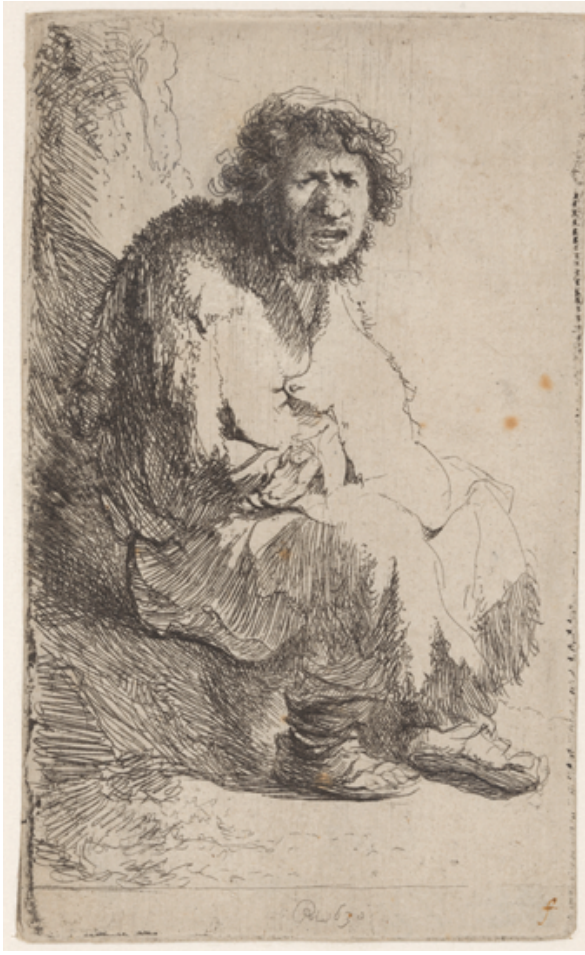

Fig. 8. Rembrandt, Self-Portrait as beggar, Amsterdam, Rijksmuseum (C) Amsterdam, Rijksmuseum

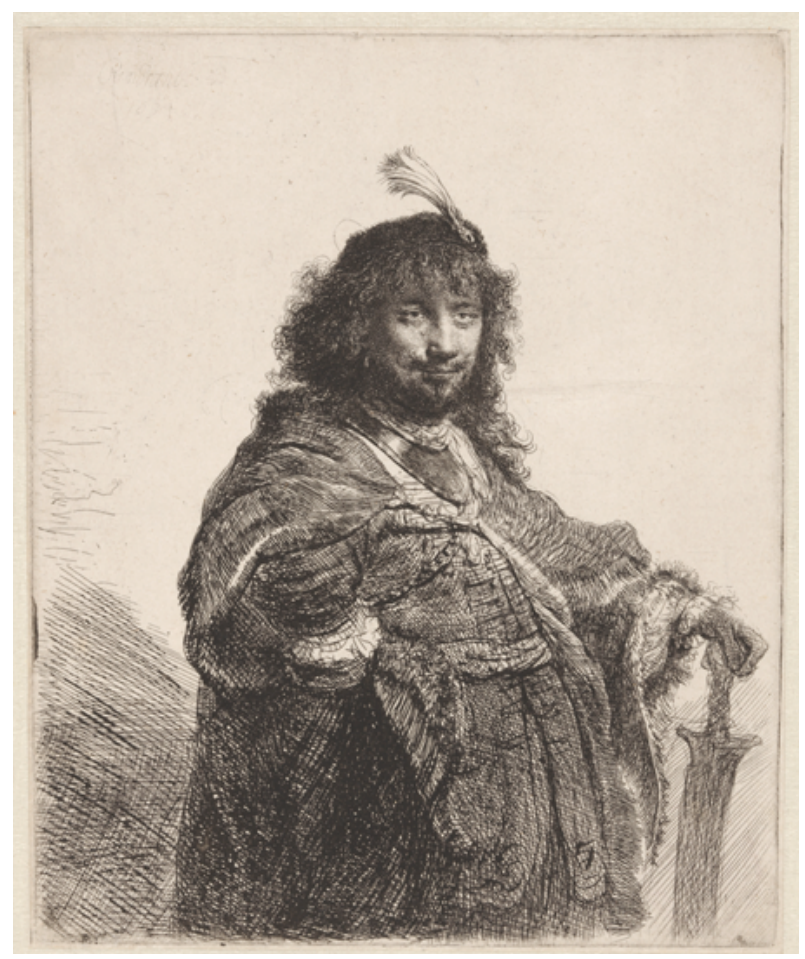

Fig. 10. Rembrandt, Self-Portrait with Plumed Cap and Oriental Sabre, Amsterdam, Rijksmuseum (C) Amsterdam, Rijksmuseum

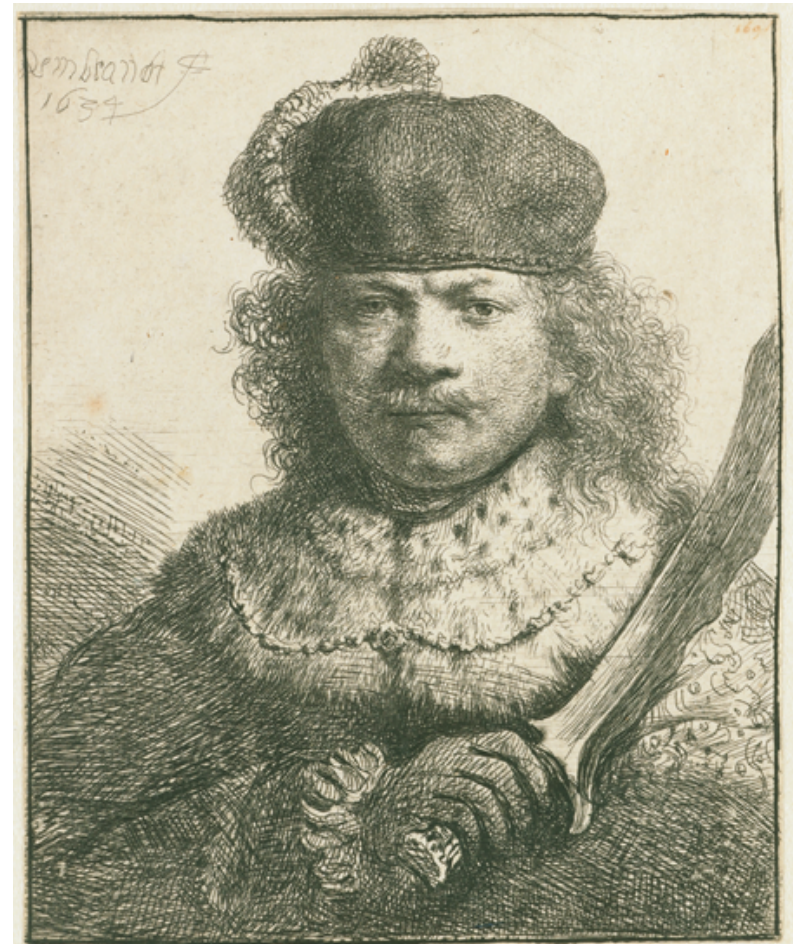

Fig. 9. Rembrandt, Self-Portrait as an Oriental Potentate with a Kris, 1634, Amsterdam, Rijksmuseum (C) Amsterdam, Rijksmuseum

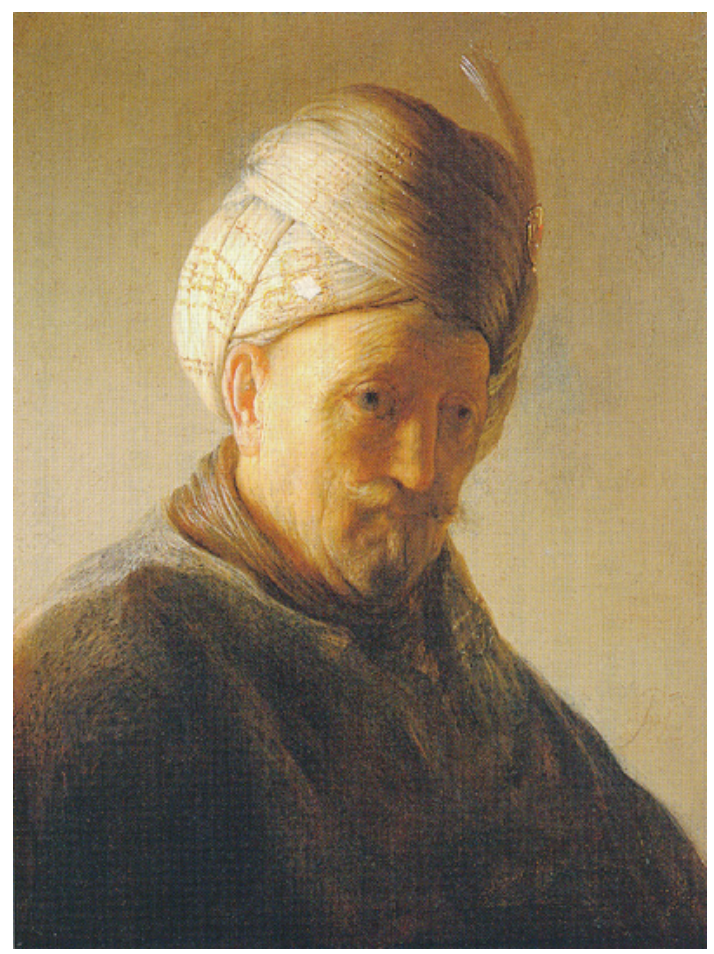

Fig. 11. Rembrandt, Bust of a man wearing a turban, c. 1628, Private collection 
Although Rembrandt had studied oriental miniatures, he was particularly intrigued by a group of drawings modeled on the miniatures of the Islamic dynasties (Fig. 12). Rembrandt's drawing of the Mughal emperor Jahangir was made as a copy of a Mughal miniature depicting Jahangir receiving an address from an official (Filipczak, 2007-08: 165-166). The miniatures Rembrandt used as models had been made between 1628 and 1658 by the court painter of Shah Jahan (who reigned from 1628 to 1658), fifth emperor during the zenith of the Mughal dynasty which ruled over a large part of India. In both the miniature and the drawing, the scene shows the official as he hands over a report to the emperor. The figures are pictured opposite each other, in profile, and there is a tense, solemn atmosphere. The miniature, however, portrays the rigid caste system and the clear hierarchical distinctions between the emperor and his vassal. The emperor is seated on a divan as he receives the report, and as a result he is raised above the vassal, and his body, exuding greatness, is drawn slightly larger than that of the vassal.

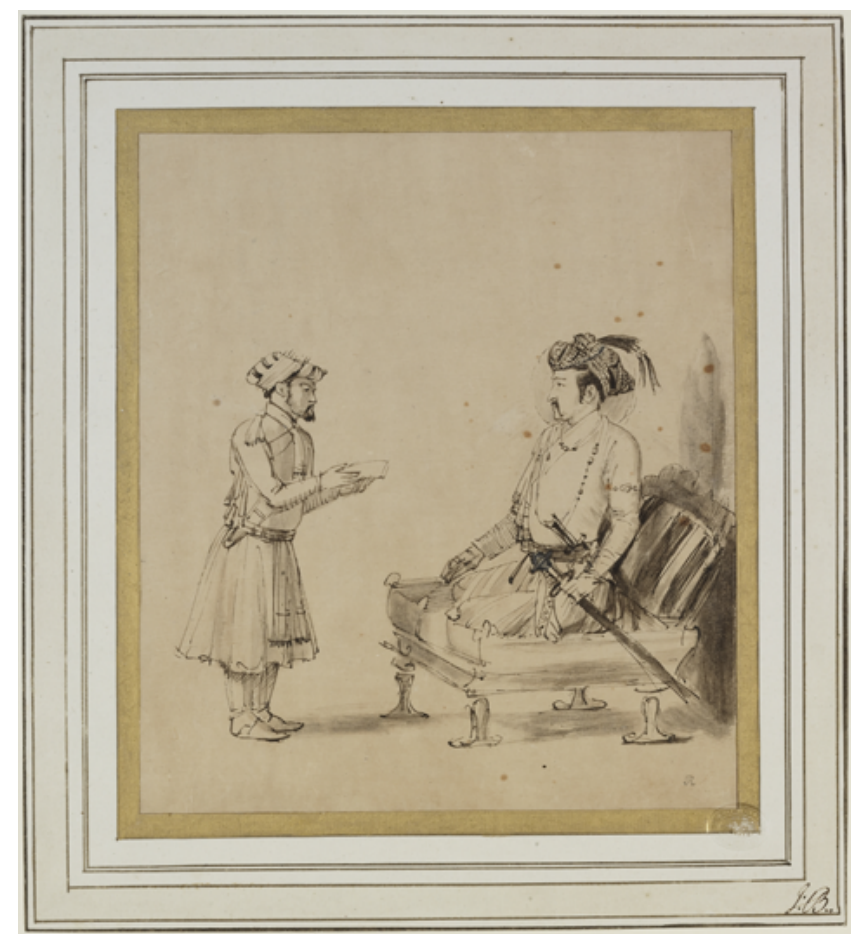

Fig. 12. Rembrandt, Jahangir receiving an address, London, British Museum (C) London, British Museum 
However, in Rembrandt's drawing the scene has been altered. Rather than looking up towards the emperor, the vassal is leaning forward slightly, as if he wanted to look the emperor directly in the eye. There is little sense of the hierarchical norms that should be observed, and more an atmosphere of a friendly dialogue between two equals. Further intimacy is lent to the scene by omitting the background as seen in the miniature. The descriptive details of both the picture and the expression, denoting the respective positions of the people in conference, along with the suppression of depth, and so on, have tapped into a certain expressiveness, creating an intimate atmosphere. In short, the essence of this work is the way in which Rembrandt shifted the focal point onto the relationship between the two people, despite having modeled his drawing on Mughal dynasty miniatures.

In his reworking of Mughal dynasty miniatures, Rembrandt did not use white western paper, but sepia-tinted Japanese paper. Indeed, Japanese paper has a soft, sepia-colored, neutral surface, making it ideal for drawing small detail, but also excellent for creating shades of deep black. Although by using the Mughal dynasty miniatures as his models Rembrandt uncovered the concise nature of oriental art, he was also inspired by the profound sense of compassion he discovered. This was manifested in his later years in works such as The Return of the Prodigal Son (Fig. 13).

Thanks to his study of oriental miniatures, Rembrandt did not seek to express emotional depth through the use of gesture and movement, the preferred traditional methods typically used in European painting. By simply painting two people in a soothing embrace, he evoked the powerful bond of love between them, with their calm exterior and the inner turmoil of the people crying providing a stark contrast. In short, in order to convey deep, overwhelming emotion between people, there must be, paradoxically, a quiet, silent space where no one speaks. Rembrandt had learned that a person's inner world could be shown in this way. In the East, there existed an art form that could express the profound bond between people by means of a silent space, one which was not to be found in Europe during Rembrandt's time.

Rembrandt, too, saw oriental art not so much as art in itself but as a method of expressing the innermost feelings that were still lacking in European art, and that were understood as a source of inspiration for the creation of a new, ideal form of human compassion.

In the same way, van Gogh immersed himself in the "Japanese" world, such a vital source of inspiration for his creation of a profoundly authentic 


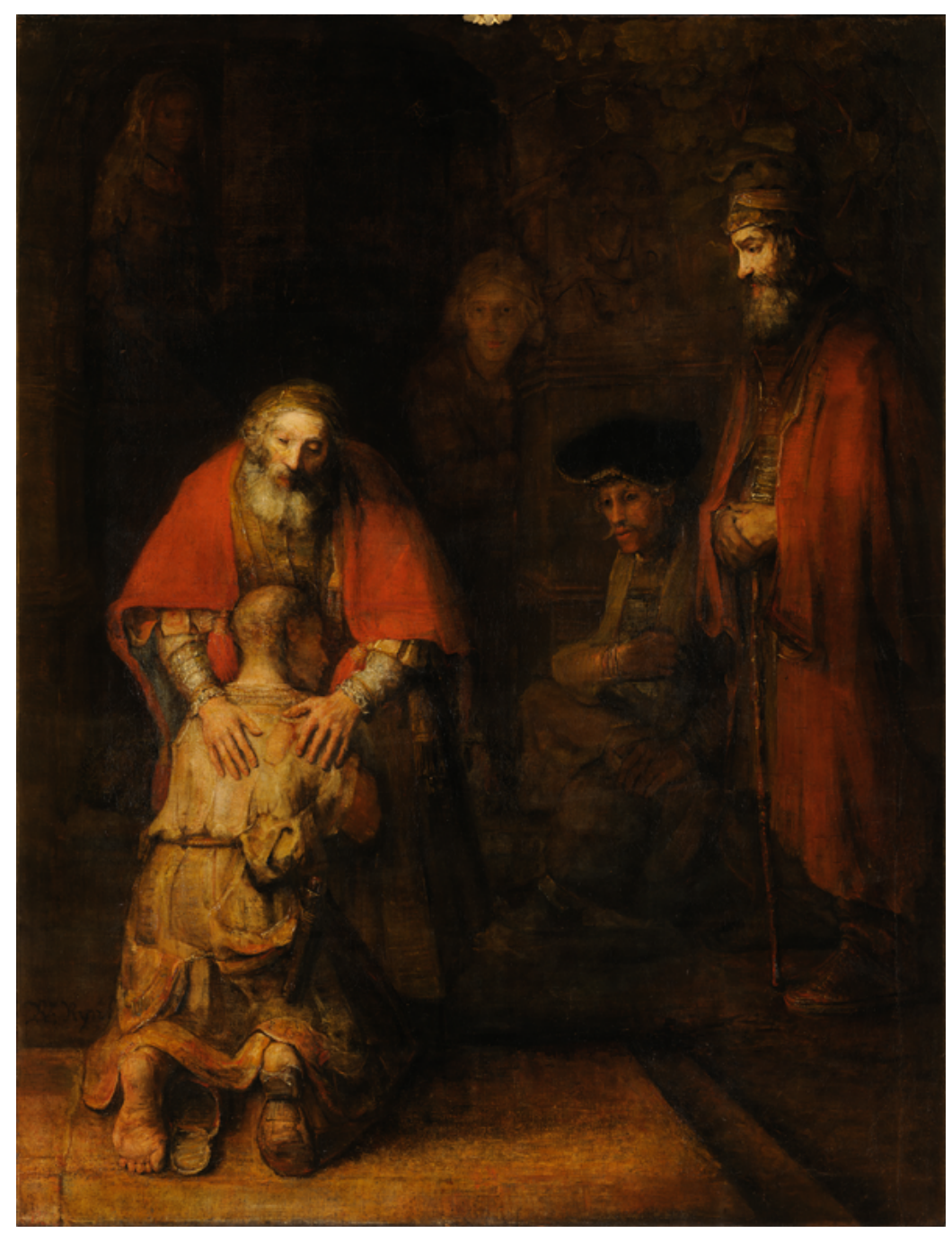

Fig. 13. Rembrandt, The Return of the Prodigal Son, Saint Petersburg, Hermitage Museum (open domain)

form of art, leading him to paint his own soul and the soul of the people of his time in a way that had never been seen before in European art. Similarly, van Gogh's art was distilled into a more essential form of itself as the inspiration from the ukiyo-e genre gradually deepened and became more internalized. Therefore, this is something he shared with Rembrandt and what related him more closely to the oriental art apparent in work of the Old Master. 


\section{BIBLIOGRAPHY}

Brook, T. (2007). Vermeer's Hat: The Seventeenth Century and the Dawn of the Global World. London: Bloomsbury Publishing.

Cooper, D. (Ed.). (1983). Paul Gauguin: 45 Lettres à Vincent, Théo et Jo van Gogh: Collection Rijksmuseum Vincent van Gogh, Amsterdam. 's-Gravenhage/Lausanne: Staatsuitgeverij La Bibliothèque des arts.

Exh.cat. (1989). Wunderblock. Eine Geschichte der modernen Seele (Historisches Museum der Stadt Wien). Wien: Löcker Verlag.

Exh.cat. (1989), Sievernich, G., \& Budde, H. (Eds.). Europa und der Orient 800-1900 (MartinGropius-Bau in Berlin). Gütersloh: Bertelsmann Lexikon Verlag.

Exh.cat. (1995). Van Gogh: Die Pariser Selbstbildnisse (Hamburger Kunsthalle). Stuttgart: Gerd Hatje Verlag.

Exh.cat. (1999), Van den Boogert. B. (Ed.). Rembrandt's Treasures (Rembrandt House Museum, Amsterdam). Zwolle: Waanders Publishers.

Exh.cat. (2000-01). Van Gogh Face to Face: The Portraits (Detroit Institute of Arts / Museum of Fine Arts, Boston / Philadelphia Museum of Art). London: Thames \& Hudson.

Exh.cat. (2001-02). Van Gogh and Gauguin: The Studio of the South (The Art Institute of Chicago / Van Gogh Museum, Amsterdam). New York: Thames \& Hudson.

Exh.cat. (2003). Vincent's Choice: The Musée Imaginaire of Van Gogh (Van Gogh Museum, Amsterdam). London: Thames \& Hudson.

Exh.cat. (2011-12). Edvard Munch: The Modern Eye (Centre Pompidou, Paris / Schirn Kunsthalle, Frankfurt / Tate Modern, London). London: Tate Publishing.

Exh.cat. (2012-13). Van Gogh: rêves de Japon (Pinacothèque de Paris). Paris: Editions Gourcuff Gradenigo.

Exh.cat. (2013-15). Monet, Gauguin, Van Gogh... Japanese Inspirations Museum Folkwang (Essen / Kunsthaus Zürich). Göttingen: Edition Folkwang/Steidl.

Filipczak, Z. Z. (2007-08). Rembrandt and the body language of Mughal miniatures. Body and Embodiment in Netherlandish Art / Lichaam en Lichamelijkheid in de Nederlandse Kunst, Netherlands Yearbook for History of Art. 58 (Brill), 163-187.

Gauguin, P. (1888). Letter to Vincent van Gogh, Pont-Aven, Monday, 1 October 1888, no. 692. Retrieved from http://vangoghletters.org/vg/letters/let692/letter.html.

Hulsker, J. (1996). The New Complete van Gogh Paintings, Drawings, Sketches. Amsterdam/ Philadelphia: John Benjamins Publishing Company.

Hecht, P. (2006). Van Gogh en Rembrandt. Amsterdam: Van Gogh Museum.

Jansen, L., Luijten, H., \& Bakker, N. (Eds.). (2009). Vincent Van Gogh: The letters, 6 vols. London: Thames \& Hudson.

Kōdera, T. (1990). Vincent van Gogh: Christianity versus nature. Amsterdam: John Benjamins Publishing Company.

Kōdera, T. (2009). Fan Gohho: shizen to shūkyō no tōsō [圆府寺司『ファン・ゴッホ: 自然と宗教 の闘争』,Van Gogh: Nature versus Religion]. Tōkyō: Shogakukan Inc.

Kofuku, A. (Ed.). (2018). 17 seiki Oranda bijutsu to Ajia [幸福輝編『17世紀オランダ美術と〈ア ジア〉』, 17 century Dutch Art and Asia]. Tōkyō: Chūokoron Publisher.

Lindert, J. van, \& Uitert, E. van. (1990). Vincent van Gogh en zijn Portretten. Amsterdam: Meulenhoff/Landshoff.

Lloyd, J. (2006-07). Vincent van Gogh and Expressionism, exh. cat. Amsterdam/New York: Hatje Cantz Verlag. 
Ozaki, A. (2004). Renburanto no korekushon: jikoseikei he no chōsen [尾崎彰宏『レンブラント のコレクション:自己成型への挑戦』，Rembrandt's Collection: Challenges to Self-fashioning]. Tōkyō: Sangensha.

Ozaki, A. (2014), L'impatto della sfida di Van Gogh a Rembrandt. Art History (Bijutushigaku). 35, 1-19.

Pomeranz, K. (2000). The Great Divergence: China, Europe, and the Making of the Modern World Economy. Princeton: Princeton University Press.

Wetering, E. van (Ed.). (2005). A Corpus of Rembrandt Paintings. IV. The Self-Portraits. Dordrecht: Springer.

Rappard-Boon, I. van, Gulik, W. van, \& Bremen-Ito, K. van. (2006). Japanese Prints: Catalogue of the Van Gogh Museum's Collection. Zwolle: W Books.

van Gogh, V. (1882). Letter to Theo van Gogh. Arles, Sunday, 17 or Monday, 18 September 1882, no. 265. Retrieved from http://vangoghletters.org/vg/letters/let265/letter.html.

van Gogh, V. (1888a). Letter to Theo van Gogh. Arles, Monday, 17 or Tuesday, 18 December 1888, no. 726. Retrieved from http://vangoghletters.org/vg/letters/let726/letter.html.

van Gogh, V. (1888b). Letter to Theo van Gogh. Arles, on or about Friday, 16 March 1888, no. 585. Retrieved from http://vangoghletters.org/vg/letters/let585/letter.html.

van Gogh, V. (1888c). Letter to Theo van Gogh. Arles, Tuesday, 21 February 1888. no. 577. Retrieved from http://vangoghletters.org/vg/letters/let577/letter.html.

van Gogh, V. (1888d). Letter to Theo van Gogh. Arles, Tuesday, 24 February 1888. no. 578. Retrieved from http://vangoghletters.org/vg/letters/let578/letter.html.

van Gogh, V. (1888e). Letter to Emile Bernard. Arles, Wednesday, 3 October 1888. Retrieved from http://vangoghletters.org/vg/letters/let696/letter.html.

Van Gogh, V. (1888f). Letter to Theo van Gogh. Arles, Thursday, 4 or Friday, 5 October 1888, no. 697. Retrieved from http://vangoghletters.org/vg/letters/let697/letter.html.

Van Gogh, V. (1888g). Letter to Paul Gauguin. Arles, Wednesday, 3 October 1888, no. 695. Retrieved from http://vangoghletters.org/vg/letters/let695/letter.html.

Zempel, C. (1997). Van Gogh's Progress: Utopia, Modernity, and Late-Nineteenth-Century Art. Berkley/Los Angeles/London: University of California Press. 